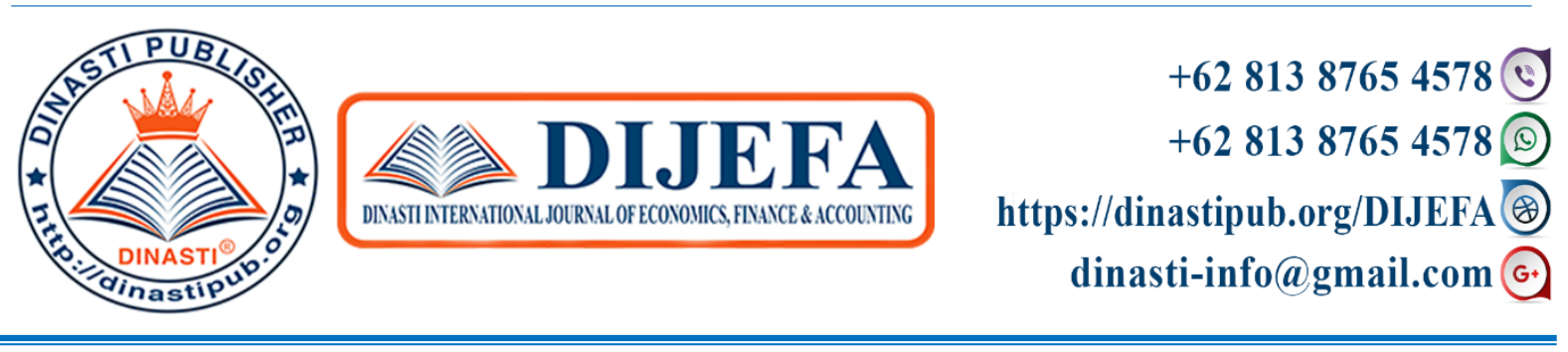

\title{
DETERMINANTS OF FUNDAMENTAL STOCK RETURN FACTORS AT TEXTILE AND GARMENT COMPANY, ANALYSIS DATA PANEL FOR PERIOD 2012 - 2019
}

\author{
P. Sihombing'), Fanny Ferdiantoputera Sinaga ${ }^{2)}$ \\ (1) Lecturer in Department of Magister Management, Mercu Buana University, Jakarta, Indonesia \\ ${ }^{(2)}$ Student at Magister Management, Mercu Buana University, Jakarta, Indonesia
}

\begin{tabular}{|c|c|}
\hline $\begin{array}{c}\text { ARTICLE INFORMATION } \\
\text { Received: } 13 \text { August } 2020 \\
\text { Revised: } 26 \text { August } 2020 \\
\text { Issued: 24 September } 2020 \\
\text { Corresponding author: first author } \\
\text { E-mail: } \\
\text { pardomuan.sihombing@mercubuana.ac.id } \\
\text { ferdixhien@gmail.com }\end{array}$ & $\begin{array}{l}\text { Abstract: This research aims to examine and analyze the } \\
\text { effect of current ratio, total asset turnover, debt to equity } \\
\text { ratio and return on equity on the value of stock of textile } \\
\text { and garment companies in the Indonesia Stock Exchange } \\
\text { for the period of } 2012 \text { to } 2019 \text {. This research uses annual } \\
\text { data for the observation period from } 2012 \text { to } 2019 \text {. The } \\
\text { population is textile and garment companies listed on the } \\
\text { Indonesia Stock Exchange in } 2012 \text { to } 2019 \text { and up to } 19 \\
\text { companies. The sampling technique used purposive } \\
\text { sampling, found a sample of } 7 \text { companies with } 8 \text { years } \\
\text { observation so that the total observation obtained was } 56 . \\
\text { The model used is the Common Effect Model. The } \\
\text { results of the analysis show that the total asset turnover } \\
\text { have a significant negative effect and return on equity } \\
\text { have a significant positive effect, while the current ratio } \\
\text { and debt to equity ratio have no significant effect on } \\
\text { stock returns of textile and garment companies in the } \\
\text { Indonesia Stock Exchange for the period of } 2012 \text { to } \\
2019 \text {. } \\
\text { Keywords: Current Ratio, Total Asset Turnover, Debt To } \\
\text { Equity Ratio, Return On Equity, Stock Returns. }\end{array}$ \\
\hline
\end{tabular}

\section{INTRODUCTION}

Indonesia Stock Exchange (IDX) is the current capital market Transaction Center. Indonesia Stock Exchange as one of the capital market that can be used as alternative funding for all sectors of the company in Indonesia. One of the funding alternatives is through the issuance and sale of stocks on the stock exchange. One of subsectors in the Indonesia Stock Exchange are the textile and garment subsector. There are 19 companies in the textile and garment subsector. The textile and garment subsector has an important role as the provider of domestic clothing needs. The textile and garment subsector has a major contribution to various aspects ranging from foreign investment (PMA), domestic investment (PMDN), export activities, foreign exchange receipts, state revenues, and gross domestic products. The textile and garment subsector is also able to open the job field and absorb the workforce which later reduce unemployment and require large funds so as to fulfill the funds the company will need funds from investors, hence the author 
is interested in researching textile and garment subsector companies in hopes of providing better information for other authors and prospective investors who want to invest in stocks.

According to Halim (2005:12), if the profits obtained by the company are relatively high, then it is likely that the dividends paid are also relatively high. A high dividend will certainly attract investors to buy company shares so that the demand for these shares will increase and of course will make the stock price also increase. Of course, the theory mentioned above can be said to be correct and can be said to be less precise because this is contrary to the facts. Several manufacturing companies in the textile and garment industry sub-sectors listed on the Indonesia Stock Exchange experienced a phenomenon where the company's stock price experienced a downward trend when net profit / loss increased or vice versa. The trend of decreasing stock prices in the textile and garment sub-sector companies can certainly affect the company's stock return, which also experiences fluctuation and a downward trend. Here is the average stock return data and average net profit/loss the textile and garment subsector that is in the IDX period 2012-2019.

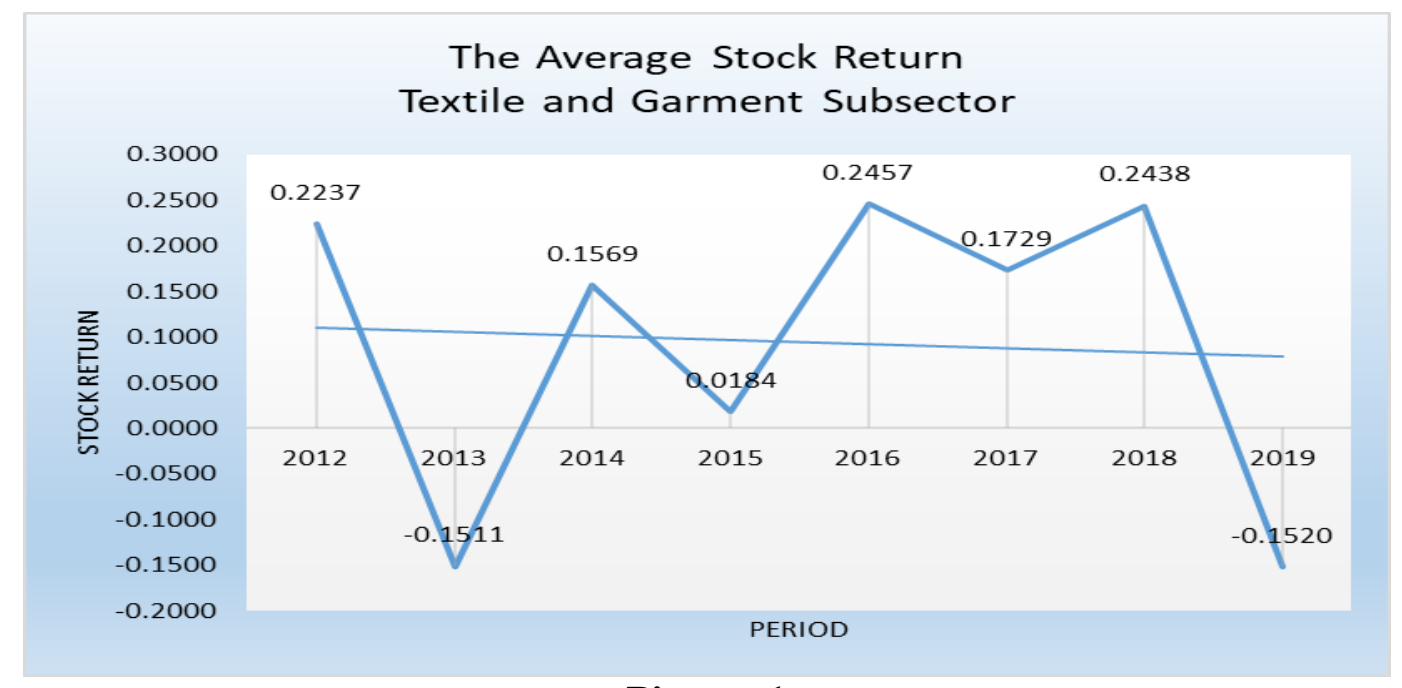

Picture 1

The Average Stock Return Data in IDX

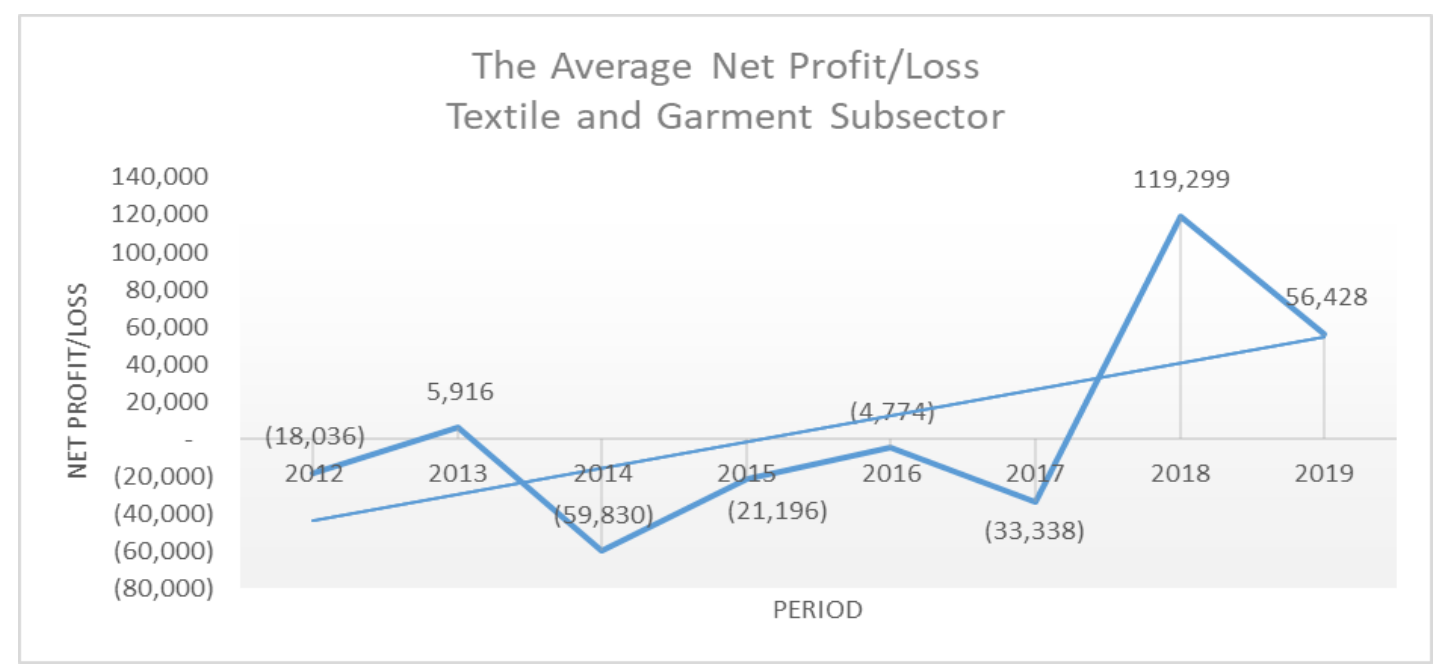

Picture 2

The Average Net Profit/Loss Data in IDX 
Based on Picture 1, it can be seen that the average stock return of textile and garment companies listed on the IDX has fluctuated and has a downward trend. The biggest decline occurred in 2019 due to the decline in stock prices of textile and garment companies in that period. Of the 19 shares of textile and garment issuers listed on the Indonesia Stock Exchange (IDX) from January 2 to September 30, 2019, there were 9 stocks that had negative returns. Some even fell by more than $50 \%$. Stocks in the textile and garment industry were exposed to a sell-off by market players driven by the depressed fundamental performance of the company due to the influx of imports in the upstream product sector and increased competition for the export market (www.cnbcindonesia.com). Meanwhile, Picture 2 shows that the company's average net profit / loss from 2012-2019 experienced an increasing trend.

Based on the phenomenon that has occurred, the researcher has a desire to analyze what factors can affect a company's stock return. One way that can be used to determine what factors can affect stock returns is by conducting financial ratio analysis or better known as the traditional approach. Financial ratios are an activity of comparing numbers in financial reports by dividing one number by another (Kasmir, 2015:104). Financial ratios can be used by investors to analyze a company's ability to generate profits by utilizing existing shares. A company's stock return can be reflected in the company's financial performance. If the company's financial performance shows an increasing prospect, the shares will be in great demand by investors and the price will also increase.

\section{LITERATURE REVIEW}

\section{Signaling Theory}

Signaling theory was first introduced by Spence in 1973 which was later developed by Ross in 1977. The theory states that the company's executives have better information about their company and will be encouraged to deliver the information to prospective investors to increase the price of the company's shares. Cues or signals are an action that a company takes to instruct investors on how management views the company's prospects. This signal is in the form of information about what management has done to realize the owner's wishes (Brigham, 2011). The information provided by the management of the company is very important because it involves the investment decisions of parties who wish to invest in the company.

\section{Capital Asset Pricing Model}

Asset pricing theories postulate that differences in expected returns are related to the covariances of securities with marginal utility. The marginal utility may depend on several economic risk factors, in which case several "betas" may be required to measure risk. Firm-specic attributes have traditionally served as alternatives to beta in tests of these asset pricing models. For example, the firm "size-effect" first drew attention as a challenge to the CAPM. The literature continued in this tradition with the ratios of stock market price to earnings and the book value of equity (e.g. Basu, 1977; Chan et al., 1991; Fama and French, 1992). The evidence of these studies suggests that such firm-specific attributes are important for explaining equity returns in the United States and Japan. Ferson and Harvey (1994), find that similar variables are important at the country level

\section{Stock Return}

According to Sihombing (2018:66) return is the actual annual income received, plus any price changes in the market, usually written as a percentage of the opening price (asset) in the market. Stock return can be defined as a level of profit obtained and expected by investors from an investment for a certain period of time that will be obtained in the future. Stock return is the result 
obtained from investment. Returns can be in the form of realized returns that have occurred or expected returns that have not occurred but which are expected to occur in the future (Umrotul, 2016).

\section{Current Ratio}

The current ratio is the ratio commonly used to measure a company's ability to meet shortterm obligations (short run solvency) that will mature within one year. Current liabilities are used as the denominator because they reflect liabilities that must be paid immediately within one year. The recommended current ratio is around 2. A current ratio that is too high, means that the company holds too many current assets. Meanwhile, current assets do not generate high returns compared to fixed assets. Conversely, current ratios that are too low or even less than 1 reflect the company's risk of not being able to meet maturing liabilities.

\section{Total Assets Turnover}

Total assets turnover is a ratio used to measure the turnover of all assets owned by the company and to measure how much sales were obtained from each rupiah of assets. According to Murhadi (2013:60), Total Asset Turnover shows the effectiveness of a company in using its assets to create revenue. The greater this ratio, the better, which means that the assets can generate profits faster and shows the more efficient and effective use of all assets in generating income.

\section{Debt to Equity Ratio}

Debt to Equity Ratio (DER) is a leverage ratio (solvency) which measures the ratio between external capital and own capital. According to Kasmir (2015:157) debt to equity ratio (DER) is a ratio used to assess debt to equity. To find this ratio by comparing all debt, including current debt, and all equity. According to Sutrisno (2012:218) Debt to Equity Ratio (DER) is a balance between debt owned by a company with its own capital. The higher this ratio means that the amount of debt is greater than the equity itself.

\section{Return On Equity}

According to Kasmir (2015: 201), the return on equity (ROE) or the profitability of capital itself is a ratio to measure net profit after tax with its own capital. Because in general, profit is a measure used by investors in determining whether the company where the investor will invest is promising or not. This ratio shows the efficient use of own capital. The higher this ratio, the better. This means that the position of the company owner is getting stronger, and vice versa. Return on Equity usually describes whether shareholders receive a reasonable return on their investment.

\section{METHODOLOGY}

\section{Research methods and variables}

The research method used is an associative research method with a quantitative approach. Associative research is research that aims to determine the relationship between two or more variables (Sugiyono, 2012:55). Associative research is conducted to determine whether there is an effect of the current ratio, total asset turnover, debt equity ratio and return on equity to stock returns either partially or simultaneously. There is also an analysis of the research carried out by quantitative methods which aim to test the hypothesis. Quantitative research methods can be interpreted as a research method based on the philosophy of positivism, used to research specific populations or samples, data collection using research instruments, quantitative / statistical data analysis with the aim of testing predetermined hypotheses (Sugiyono, 2017: 8).

\section{Analysis tools and regression models}


In analyzing this research author using the E-Views vers tool. 9.0. or higher. The analysis used to examine and answer the effect of the current ratio, total asset turnover, debt equity ratio and return on equity to stock returns either partially or simultaneously is by using Panel Data Regression Analysis approach. The data regression analysis panel is used to examine the hypotheses that have been filed in the research. The data panel is a combination of cross-section and time series. The data regression Model of the panel can be formulated as follows :

$$
\begin{gathered}
\text { Return }=\alpha+\beta_{1} \mathrm{CR}_{\mathrm{it}}+\beta_{2} \mathrm{TATO}_{\mathrm{it}}+\beta_{3} \mathrm{DER}_{\mathrm{it}}+\beta_{4} \mathrm{ROE}_{\mathrm{it}} \\
\mathrm{i}=1,2, \ldots \ldots . ., \mathrm{N} ; \quad \mathrm{t}=1,2, \ldots \ldots \mathrm{T}
\end{gathered}
$$

Description:

$\begin{array}{ll}\text { Return } & =\text { Stock Returns } \\ \text { CR } & =\text { Current Ratio } \\ \text { TATO } & =\text { Total Asset Turnover } \\ \text { DER } & =\text { Debt To Equity Ratio } \\ \text { ROE } & =\text { Return On Equity } \\ \alpha & =\text { Constants } \\ \beta & =\text { Regression Coefficient } \\ \text { E } & =\text { Residual Error }\end{array}$

\section{RESULTS OF RESEARCH AND EXPLANATION Descriptive Data}

Descriptive statistics are intended to provide an overview or explanation of the data of a variable that is researched, variables used include, current ratio, total assets turnover, debt to equity ratio and retun on equity to stock returns. From the results of descriptive statistical analysis to the five variables with the research sample $(n=56)$, and the results have been depicted on the table below.

Table 1 Descriptive Statistical Analysis Results

\begin{tabular}{lccccc} 
& STOCK_RETURN & CR & TATO & DER & ROE \\
\hline \hline Mean & 0.089777 & 1.831973 & 0.891839 & 1.327897 & 0.050150 \\
Median & 0.000000 & 1.264212 & 0.994882 & 1.290000 & 0.034650 \\
Maximum & 3.740000 & 6.505906 & 1.496908 & 3.996260 & 0.307400 \\
Minimum & -0.816667 & 0.403100 & 0.135411 & 0.183200 & 0.000400 \\
Std. Dev. & 0.598154 & 1.410005 & 0.447953 & 0.816676 & 0.058844 \\
Skewness & 4.236205 & 2.104801 & -0.482443 & 0.979565 & 2.029937 \\
Kurtosis & 26.18552 & 7.093504 & 1.803321 & 3.786138 & 8.234181 \\
& & & & & \\
Jarque-Bera & 1421.816 & 80.44756 & 5.513778 & 10.39782 & 102.3849 \\
Probability & 0.000000 & 0.000000 & 0.063489 & 0.005523 & 0.000000 \\
& & & & & \\
Sum & 5.027493 & 102.5905 & 49.94297 & 74.36222 & 2.808388 \\
Sum Sq. Dev. & 19.67833 & 109.3462 & 11.03642 & 36.68282 & 0.190442 \\
& & & & & \\
Observations & 56 & 56 & 56 & 56 & 56 \\
\hline \hline
\end{tabular}

Source: Data processing result with Eviews version 9.0, (2020). 
1. The stock return variable shows a minimum value of -0.816667 . The negative number of the minimum value is because there are several sample companies that have negative stock returns three times or more during the study period. And the maximum value is 3.740000 . And the company average has a stock return value of 0.089777 with a standard deviation of 0.598154 (above the average). It can also be seen in the stock return variable, the standard deviation value is greater than the mean. It can be concluded that stock returns have a high level of data variation and there is a large fluctuation of the stock return variable for textile and garment companies on the IDX.

2. The current ratio variable shows a minimum value of 0.403100 and a maximum value of 6.505906. The average company has a current ratio value of 1.831973 , this shows that every Rp 1 current liabilities can be fulfilled with 1.831973 current assets owned by the company. The standard deviation value of the current ratio is 1.410005 (below the average), indicating that the current ratio has a low level of data variation and there is no large fluctuation of the current ratio variable against textile and garment companies on the IDX.

3. The total asset turnover variable shows a minimum value of 0.135411 and a maximum value of 1.496908. The average company has a total asset turnover value of 0.891839 , this shows that every Rp 1 of the company's assets can generate 0.891839 times sales. The standard deviation value is 0.447953 . (below average), indicating that the total asset turnover has a low level of data variation and there is no large fluctuation of the total asset turnover variable for textile and garment companies on the IDX.

4. The debt to equity ratio variable shows a minimum value of 0.183200 and a maximum value of 3.996260. The average company has a debt to equity ratio of 1.327897 , this shows that every Rp. 1 of equity the company has is used to finance Rp. 1, 327897 of the company's liabilities. The standard deviation value is 0.816676 (below the average), indicating that the debt equity ratio has a low level of data variation and there is no large fluctuation of the debt equity ratio variable against textile and garment companies on the IDX.

5. The return on equity variable shows a minimum value of 0.000400 and a maximum value of 0.307400 . The average company has a return on equity value of 0.050150 , this shows that for every Rp. 1 of equity the company can generate Rp. 0.050150 profit. The standard deviation value is 0.058844 (above the average), indicating that the return on equity has a high level of data variation and there is a large fluctuation of the return on equity variable for textile and garment companies on the IDX.

\section{Data Regression Analysis Panel}

Table 2 Conclusion Testing Model Data Regression Panel

\begin{tabular}{llcc}
\hline \hline No & \multicolumn{1}{c}{ Method } & p-value $(\boldsymbol{\alpha}=\mathbf{0 , 0 5})$ & Result \\
\hline \hline 1 & Chow-Test & 0.1657 & Common Effect \\
2 & Lagrange Multiplier-BP & 0.6706 & Common Effect \\
3 & Hausman Test & 0.4153 & Random Effect \\
\hline \hline
\end{tabular}

The data regression analysis of the panels used in the hypothesis testing is to test the effect of current ratio, total assets turnover, debt to equity ratio and return on equity on stock returns. From the two previous tests, namely the Chow Test and the LM Breusch-Pagan (BP), it was concluded that the authors' data would be more appropriate using the Common Effect Model (CEM). Here is an Eviews output for the data regression panel using the Common Effect Model (CEM). 
Table 3 Panel Data Regression Analysis Results

\begin{tabular}{crrrr}
\hline \hline Variable & Coefficient & Std. Error & t-Statistic & Prob. \\
\hline \hline C & 0.130204 & 0.214019 & 0.608378 & 0.5456 \\
CR & 0.027404 & 0.055157 & 0.496845 & 0.6214 \\
TATO & -0.599137 & 0.237738 & -2.520156 & 0.0149 \\
DER & 0.113949 & 0.109154 & 1.043925 & 0.3014 \\
ROE & 5.830326 & 1.625833 & 3.586054 & 0.0008 \\
\hline \hline R-squared & 0.210080 & Mean dependent var & 0.089777 \\
Adjusted R-squared & 0.148125 & S.D. dependent var & 0.598154 \\
F-statistic & 3.390872 & Durbin-Watson stat & 2.170871 \\
Prob(F-statistic) & 0.015546 & & \\
\hline \hline
\end{tabular}

Source: Data processing results with Eviews version 9.0, (2020)

\section{Impact of current ratio on stock returns}

The first hypothesis (H1) which states that the current ratio has a positive effect on stock returns, is rejected. This shows that the current ratio has no significant effect on stock returns. The results of this study are in line with research conducted by Erik Setiyono and Lailatul Amanah (2016) and Ihsan S. Basalama, Sri Murni, Jacky S.B. Sumarauw (2017) which states that the current ratio has no effect on stock returns, but it is not in line with previous research conducted by Yuliya Wingsih (2013), Khairani Purnamasari et. al (2014) and Sugiarti (2015). The current ratio is used to measure the company's ability to meet its short-term debt by using its current assets (assets that will turn into cash within one year or one business cycle). The ability of a company to pay off its short-term obligations on time or at maturity can lead to good prospects from investors to the company. With a good perspective, it will generate interest in investing, so that the supply and demand for shares can occur which in turn has an impact on changes in the company's stock return.

In the research results, the current ratio does not have a significant effect on company stock returns, this is probably because most companies in the study are still affected by the impact of the crisis experienced by this industry so that the overall ability of current assets available in the company is not good enough. In addition, the interpretation of this ratio can be different for several industries, not only for manufacturing and non-manufacturing, so it needs a reinterpretation of how much the current ratio is acceptable for each specific different industry. Thus it can be said that investors in predicting stock returns cannot consider the current ratio in making decisions.

\section{Impact of total assets turnover on the stock returns}

The second hypothesis $(\mathrm{H} 2)$ which states that total asset turnover has a negative effect on stock returns, is accepted. This shows that total asset turnover has a significant effect on stock returns. The results of this study are in accordance with the hypothesis proposed in the study and also in line with previous research conducted by Dwi Martani, Mulyono and Rahfiani Khairurizka (2009) and Ajeng Ika Ariyanti and Suwitho (2016) regarding total asset turnover which states that total asset turnover has a significant effect. to stock returns. However, the results of this study contradict the research of Tri Laksita Asmi (2014), Chrismas Bisara and Lailatul Amanah (2015) and Farda Eka Septiana and Aniek Wahyuati (2016) which states that total asset turnover has no significant effect on stock returns. Total asset turnover is measured by sales volume, meaning that the ability of all assets to create sales can certainly increase profits. However, this can be a consideration for investors because not always profit can be used by investors' interests. Profits 
can be used to pay corporate debts, therefore investors can consider this ratio in predicting stock returns.

\section{Impact of debt to equity ratio on stock returns}

The third hypothesis (H3) which states that the debt to equity ratio has a negative effect on stock returns, is rejected. This shows that the debt to equity ratio has no significant effect on stock returns. The results of this study are in line with previous research conducted by Sari Oktavera (2016) and Gharaibeh (2014) who said that debt to equity ratio has no effect on stock returns. However, this is not in line with or inconsistent with the results of research by Ayu Kemala Putri (2016), Sari (2016) and Moh. Zainuddin Arief et al (2017) who show that the debt to equity ratio has a significant effect on stock returns. Debt equity ratio is a ratio of lavarage (solvency) which can describe the level of risk of a company due to the use of debt for its operating activities. Debt To Equity Ratio (DER) can be used to measure the extent to which owner's capital can cover debts to outsiders. A high debt to equity ratio indicates the dependence of the company's capital on outsiders and affects the company's performance. This will reduce shareholder rights (in the form of dividends), as well as reduce investor interest in the company's shares because the rate of return is getting smaller. From the results of this study, it can be concluded that the real condition of investors before investing their capital cannot be fixed or focused on the value of a company's debt to equity ratio. This may be due to losses incurred by companies from the previous period which resulted in changes in equity that can be distributed to owners of the parent entity.

\section{Impact of return on equity on stock returns}

The fourth hypothesis (H4) which states that return on equity has a positive effect on stock returns, is accepted. This shows that return on equity has a significant effect on stock returns. The results of this study are in accordance with the hypothesis proposed in the study and also in line with research previously conducted by Michael Aldo Carlo (2014), Neni Awika Andansari, Kharis Raharjo, Rita Andini (2016) and Arifah Rusydina and Sugeng Praptoyo (2017) regarding return on equity which states that return on equity has a significant effect on stock returns. However, the results of this study contradict the research of Mutiara Tumonggor, Sri Murni, Paulina Van Rate (2017) and Ayu Nurhayani Aisah and Kastawan Mandala (2016) which state that return on equity has no significant effect on stock returns. From the research results, it can be said that investors in predicting stock returns can consider return on equity in making investment decisions. The higher the return on equity means the better the company's performance in managing its capital to generate profits for shareholders. The value of return on equity itself has no limits, because return on equity is the ability to earn profits, so it has no limitations. With an increase in net income, the return on equity value will also increase so that investors are interested in buying these shares, which in turn will increase the company's stock return.

\section{Impact of current ratio, total assets turnover, debt to equity ratio and return on equity affect stock returns}

The results of the fifth hypothesis research (H5) which states that the current ratio, total asset turnover, debt to equity ratio and return on equity have a positive effect on stock returns. So that the results obtained indicate that the current ratio, total asset turnover, debt equity ratio and return on equity have a significant effect on the stock return variable.

\section{CONCLUSION}

1. There is no effect of the current ratio on stock returns in textile and garment companies listed on the Indonesia Stock Exchange (IDX) for the period 2012-2019. 
2. There is a negative effect of total asset turnover on stock returns in textile and garment companies listed on the Indonesia Stock Exchange (BEI) for the period 2012-2019.

3. There is no effect of the debt equity ratio on stock returns in textile and garment companies listed on the Indonesia Stock Exchange (BEI) for the period 2012-2019.

4. There is a positive effect of return on equity on stock returns in textile and garment companies listed on the Indonesia Stock Exchange (BEI) for the period 2012-2019.

5. Simultaneously there is a significant effect of the current ratio, total asset turnover, debt equity ratio and return on equity to stock returns in textile and garment companies listed on the Indonesia Stock Exchange (BEI) for the period 2012-2019.

\section{REFERENCES}

1. Abdul, Halim. (2005). Analisis Investasi. Edisi Kedua. Salemba Empat. Alfabeta. Jakarta.

2. Abdulah dan Tooheen. (2015). "The impact of financial leverage and market size on stock returns on the Dhaka stock exchange: Evidence from selected stocks in manufacturing sector". International Journal of Economics, Finance, and Management Sciences, Vol. 3, No. 1, 2015.

3. Abhimada. (2016). "The influence of profitability ratio, market ratio, and solvency ratio on the share prices of companies listed on LQ 45 Index". The Indonesian Accounting Review, Vol. 6, No. 1, January - July 2016, pages 55-66.

4. Acheampong. (2014). "The Effect of Financial Leverage and Market Size on Stock Returns on the Ghana Stock Exchange: Evidence from Selected Stocks in the Manufacturing Sector". International Journal of Financial Research, Vol.5 No.1.

5. Ajeng Ika Ariyanti dan Suwitho. (2016). "Pengaruh CR, TATO, NPM dan ROA Terhadap Return Saham”. Jurnal Ilmu dan Riset Manajemen, Vol. 5, No. 4, April 2016, hal 1-16.

6. Al-Qudah. (2013). "The Impact of Macroeconomic Variables and Banks Characteristics on Jordanian Islamic Banks Profitability: Empirical". Evidence Journals International Business Research, Vol. 6, No. 10 (2013), Issn(Print): 1913-9004 Issn(Online): 19139012.

7. Angelin S. Kiruba and Dr.S.Vasantha. (2020). "The Impact of Accounting ratios on Stock Returns: The Case of India's Chemical Industry". Adalya Journal, Volume 9, Issue 1, January 2020 ISSN NO: 1301-2746, page 362-371.

8. Arifah Rusydina dan Sugeng Praptoyo. (2017). "Pengaruh Rasio Keuangan Terhadap Return Saham". Jurnal Ilmu dan Riset Akuntansi, Vol. 6, No. 7, Juli 2017, hal 1-18: eISSN: 2460-0585.

9. Ayu Kemala Putri. (2016). "Pengaruh Corporate Social Responsibility terhadap Nilai Perusahaan dengan Ukuran Perusahaan dan Jumlah Dewan Komisaris sebagai Variabel Pemoderasi (Studi pada Perusahaan Manufaktur yang terdaftar Bursa Efek Indonesia)". Jurnal Aplikasi Manajemen, Vol. 14, No. 2, Terakreditasi SK DIRJEN DIKTI NO. 66b/DIKTI/KEP/2011 ISSN: 1693-5241.

10. Ayu Nurhayani Aisah dan Kastawan Mandala. (2016). "Pengaruh Return On Equity, Earning Per Share, Firm Size dan Operating Cash Flow Terhadap Return Saham”. E-Jurnal Manajemen Unud, Vol. 5, No. 11, 2016: hal 6907-6936 ISSN : 2302-8912.

11. Basu, S. (1977). The investment performance of common stocks in relation to their priceearnings ratios: A test of the e $\bullet$ cient markets hypothesis. Journal of Finance 32, $663 \pm 682$.

12. Benyamin. Ivan Agavito., Endri, Endri. (2019). Determinants of Stock Returns of Building Construction Companies Listed on the Indonesia Stock Exchange Period 2012-2016, Scholars Journal of Economics, Business and Management, 6(1): 39-47. DOI: 10.21276/sjebm.2019.6.1.6.

13. Bhandari, Laxmi Chand. (1988). Debt/Equity Ratio and Expected Common Stock Returns: Empirical Evidence, Journal of Finance 43: 507-528. 
14. Brigham, Eugene F. dan Joel F. Houston. (2011). Manajemen Keuangan. Erlangga. Jakarta.

15. Chan, L.K.C., Hamao, Y., Lakonishok, J. (1991). Fundamentals and stock returns in Japan. Journal of Finance 46 (5), 1739-1764.

16. Chrismas Bisara dan Lailatul Amanah. (2015). "Pengaruh Kinerja Keuangan Terhadap Return Saham”. Jurnal Ilmu \& Riset Akuntansi, Vol. 4, No. 2.

17. Budhi Suparningsih. (2017). "Effect of Debt To Equity Ratio (DER), Price Earnings Ratio (PER), Net Profit Margin (NPM), Return On Investment (ROI), Earning Per Share (EPS) In Influence Exchange Rates and Indonesian Interest Rates (SBI) Share Price In Textile and Garment Industry Indonesia Stock Exchange". International Journal of Multidisciplinary Research and Development, Online ISSN: 2349-4182, Print ISSN: 23495979, Vol. 4, Issue 11, Page No. 58-62.

18. Dwi Martani, Mulyono dan Rahfiani Khairurizka. (2009). "The Effect of Financial Ratios, Firm Size and Cash Flow From Operating Activities In The Interim Report To The Stock Return”. Chinese Business Review, Volume 8, No.6 (Serial No.72), Jun. 2009, ISSN 15371506, page 44-55.

19. Endri. (2018). Factors Determine Stock Return of Livestock Feed Companies: Common Effect Model Analysis. International Journal of New Technology and Research (IJNTR), 4(5), 106-113.

20. Erik Setiyono. (2016). "Pengaruh Kinerja Keuangan dan Ukuran Perusahaan terhadap Return Saham". Jurnal Ilmu dan Riset Akuntansi, Vol 5 No. 5 2016; ISSN 2460-0585.

21. Fama, E.F., French, K.R. (1992). The cross-section of expected returns. Journal of Finance 47, 427- 465.

22. Farda Eka Septiana dan Aniek Wahyuati. (2016). "Pengaruh Rasio Keuangan Terhadap Return Saham Pada Perusahaan Manufaktur". Jurnal Ilmu dan Riset Manajemen, Vol.5, No.1, Januari 2016, hal 1-21.

23. Ferson, W.E., Harvey, C.R. (1994). An exploratory investigation of the fundamental determinants of international equity market returns. In: Frankel, J.A. Internationalization of Equity Markets, University of Chicago Press (ISBN 0-226-26001-1), pp. 59-148.

24. Fitri Piralanasia dan Matrodji Mustafa. (2018). “Analysis of Fundamental Factors' Effect on Stock Return of Property: A Case Study of Property, Real Estate, and Building Construction Sector of Companies Listed on The Indonesia Stock Exchange In 20122016". RJOAS, 5(77), May 2018, hal 38-47.

25. Gharaibeh. (2014). "Capital Structure, Liquidity and Stock Returns". European Scientific Journal, Vol. 10, No. 25, ISSN: 1857 - 7881 (Print) e-ISSN 1857 - 7431.

26. Ghi. (2015). "Overvaluation and Earnings Management". Journal of Banking \& Finance, Vol. 33, No. 9, page 1652-1663.

27. Hakki Öztürk dan Tolun A. Karabulut. (2018). "The Relationship Between Earnings-toPrice, Current Ratio, Profit Margin and Return: An Empirical Analysis on Istanbul Stock Exchange". Accounting and Finance Research, Vol. 7, No. 1.

28. Ihsan S. Basalama, Sri Murni, Jacky S.B. Sumarauw. (2017). "Pengaruh Current Ratio, DER dan ROA Terhadap Return Saham Pada Perusahaan Automotif Dan Komponen Periode 2013-2015". Jurnal EMBA, Vol. 5, No.2, Juni 2017, Hal. 1793-1803.

29. Kasmir. (2015). Analisis Laporan Keuangan. Edisi keduabelas. PT. Raja Grafindo Persada. Jakarta.

30. Khairani Purnamasari, Emrinaldi Nur DP, Raja Adri Satriawan S. (2014). "Pengaruh Current Ratio (CR), Debt To Equity Ratio (DER), Return On Equity (ROE), Price Earning Ratio (PER) dan Earning Per Share (EPS) Terhadap Return Saham Pada Perusahaan Property and Real Estate yang Terdaftar Di Bursa Efek Indonesia Tahun 2009-2011". Jom FEKON, Vol. 1, No. 2, Oktober 2014. 
31. Maryyam Anwaar. (2016). "Impact of Firms' Performance on Stock Returns (Evidence from Listed Companies of FTSE-100 Index London, UK)". Global Journal of Management and Business Research Accounting and Auditing, Volume 16 Issue 1 Version 1.0 Year 2016, ISSN: 2249-4588 \& Print ISSN: 0975-5853.

32. Michael Aldo Carlo. (2014). "Pengaruh Return On Equity, Dividend Payout Ratio dan Price To Earnings Ratio Pada Return Saham”. E-Jurnal Akuntansi Universitas Udayana, 7.1 (2014), hal 150-164, ISSN: 2302-8556.

33. Moh. Zainuddin Arief et al. (2017). "Pengaruh EPS, DER dan PER Terhadap Return Saham Pada Perusahaan Makanan dan Minuman Yang Terdaftar di Bursa Efek Indonesia Periode Tahun 2014-2016". E-Jurnal Riset Manajemen PRODI MANAJEMEN.

34. Murhadi, Werner R. (2013). Analisis Laporan Keuangan, Proyeksi dan Valuasi Saham. Salemba Empat. Jakarta.

35. Mutiara Tumonggor, Sri Murni, Paulina Van Rate. (2017). "Analisis Pengaruh Current Ratio, Return On Equity, Debt To Equity Ratio dan Growth Terhadap Return Saham Pada Cosmetics and Household Industry Yang Terdaftar di BEI Periode 2010-2016”. Jurnal EMBA, Vol.5, No.2 Juni 2017, Hal. 2203 - 2210.

36. Neni Awika Andansari dkk. (2016). "Pengaruh Return On Equity (ROE), Price Earning Ratio (PER), Total Asset Turn Over (TATO) dan Price To Book Value (PBV) Terhadap Return Saham (Studi Kasus Pada Perusahaan Manufaktur Sektor Makanan Dan Minuman Yang Terdaftar di BEI Periode 2008-2014)”. Journal Of Accounting, Vol. 2, No. 2, 2016.

37. Ouma, et. Al. (2014). "The Impact of Macroeconomic Variables on Stock Market Returns In Kenya". International Journal of Business and Commerce, Vol. 3, No.11: July.

38. Ross, S. A. (1977). The determination of financial structure: The incentive signaling structure. Bell Journal of Economics, 8: 23-40

39. Said Djamaluddin, Diny Rahmawati and Hapzi Ali. (2017). "The Influence of Fundamental Factors Micro and Macro to Return Expected Through The Intervening Corporate Value in The Listed Real Estate Sector in Bei Periode 2011-2014”. International Journal of Business and Management Invention (IJBMI), Volume 6, Issue 2, February. 2017, ISSN (Online): 2319 - 8028, ISSN (Print): 2319 - 801X, page 14-22.

40. Said Djamaluddin, Jhesyca Resiana and Djumarno. (2018). "Analysis the Effect of NPM, DER and PER on Return Share of Listed Company in Jakarta Islamic Index (JII) Period 2011 -2015". International Journal of Business and Management Invention (IJBMI), Vol.7, Issue 2 Ver.II, ISSN (Online): 2319 - 8028, ISSN (Print): 2319 - 801X, page 58-66.

41. Sajjad Hossine Sharif. (2019). "The Impact of Capital Structure on Stock Return of Selected Firms in the Pharmaceutical and Chemical Sector in Bangladesh". International Journal of Social Sciences Perspectives, Vol.5, No.1, 2019, pp. 9-21, ISSN: 2577-7750.

42. Sari. (2016). "Analisis Pengaruh Profitabilitas Terhadap Harga Saham Pada Perusahaan Food and Beverages Yang Terdaftar Di BEI Tahun 2011-2014”. Jurnal Fakultas Ekonomi dan Bisnis Universitas Muhammadiyah Surakarta.

43. Sari Oktavera. (2016). "Analisis Pengaruh Penilaian Kinerja Keuangan Dengan Menggunakan Metode Tradisional (DER, ROA) dan Metode Konsep Baru (EVA) terhadap Return Saham (Studi Kasus Pada Perusahaan Industri Keuangan Non Bank yang Listing di BEI Pada Tahun 2010-2014)". Jurnal Ekonomi \& Bisnis Dharma Andalas, Volume 18, No. 1, Januari 2016.

44. Senyigit and Ag. (2014). "Explaining The Cross Section of Stock Returns; A Comparative Study of The United States and Turkey". World Conference on Business, Economics and Management, Procedia-Social and Behavioral Sciences, 109 (2014), page 327-332, Zirve University: Turkey.

45. Shakeel Muhammad and Gohar Ali. (2018). "The Relationship Between Fundamental Analysis and Stock Returns Based on the Panel Data Analysis; Evidence from Karachi 
Stock exchange (KSE)". Research Journal of Finance and Accounting, Vol.9, No.3, 2018, ISSN 2222-1697 (Paper) ISSN 2222-2847 (Online).

46. Sihombing, Pardomuan. (2018). Corporate Financial Management. PT Penerbit IPB Press. Bogor.

47. Sugiarti. (2015). "Pengaruh Kinerja Keuangan Perusahaan terhadap Return Saham (Studi pada Perusahaan Manufaktur yang Terdaftar di Bursa Efek Indonesia)". Jurnal Aplikasi Manajemen (JAM), Vol 13 No 2, 2015 Indexed in Accredited Google Scholar SK DIRJEN DIKTI NO. 66b/DIKTI/KEP/2011 ISSN: 1693-5241.

48. Sugiyono. (2012). Metode Penelitian Kuantitatif Kualitatif dan R\&D. Alfabeta. Bandung.

49. Sugiyono. (2017). Metode Penelitian Kuantitatif, Kualitatif dan R\&D. Cetakan Ke-26. Alfabeta. Bandung.

50. Sutrisno. (2012). Manajemen Keuangan Teori, Konsep dan Aplikasi. 8th ed. Ekonisia. Yogyakarta.

51. Tri Laksita Asmi. (2014). "Current Ratio, Debt To Equity Ratio, Total Asset Turnover, Return On Asset, Price To Book Value Sebagai Faktor Penentu Return Saham". Management Analysis Journal, Vol.3, No.2. hal 1-12.

52. Umrotul (2016). Kegagalan Perusahaan dan Reorganisasi. Jakarta

53. Ursula Tamuntuan. (2015). “Analysing The Effect of Return On Equity, Return On Assets and Earnings Per Share Toward Share Price: An Emperical Study Of Food and Beverage Companies Listed On Indonesia Stock Exchange”. Jurnal Berkala Ilmiah Efisiensi, Vol. 15, No. 5, hal 446-457.

54. Widya. (2015). "The Effect of Internal and External Factors on Stock Return: Empirical Evidence from the Indonesian Construction Subsector". Asian Journal of Business and Management, Vol. 03, Issue 05, October 2015, ISSN: 2321 - 2802.

55. Yuliya Wingsih. (2013). "Analisis Pengaruh Likuiditas, Profitabilitas dan Solvabilitas Terhadap Return Saham Pada Perusahaan Pertambangan Yang Terdaftar Di Bursa Efek Indonesia Pada Tahun 2008-2012". Jurnal Manajemen.

56. Zadeh and Radmanesh. (2014). "Fundamental and Stock Return in Pharmaeuticao Companies: a Panel Data Model of Iranian Industry". Iranan Journal of Pharmaceutical Sciences, 2013: 9 (1): 5560.

57. https://www.cnbcindonesia.com/market/20191003123029-17-104139/duh-emiten-tekstilterpukul-harga-saham-anjlok. (Retrieved March 25, 2020) 